\title{
20
}

\section{The implications of China's economic transformation for modern economics}

\author{
Justin Yifu Lin
}

China started its transition from a planned economy to a market economy at the end of 1978. In the past 28 years, China's average annual gross domestic product (GDP) growth rate was 9.7 per cent and the trade growth rate averaged 17.2 per cent. China's GDP, measured by the official exchange rate, now ranks fourth and, by purchasing power parity, second in the world. China's trade volume is currently the third largest in the world and its foreign reserves, which exceed US $\$ 1.2$ trillion, are the largest.

In the first 12 years of reform, from 1978 to 1990, China's GDP grew by 9 per cent annually and its trade volume at 15.4 per cent. During this period, urban per capita income grew 5.9 per cent annually, while that of rural areas grew at a spectacular rate of 9.9 per cent (National Bureau of Statistics 2002:17, 94, 148). Living standards in China increased significantly and disparities between urban and rural areas decreased.

In the late 1980s and early 1990s, however, the reform process was poorly understood by the economics profession and many economists had little confidence in China's transformation.' Most economists believed that a market economy should be based on private property rights-a feature that the Chinese economy apparently lacked at that time. China's state-owned enterprises were not privatised; a dual-track resource allocation system was prevalent, with state planning still playing an important role alongside markets in resource allocation. These pessimistic economists thought that although China's economic transition was blessed with beneficial initial conditions, ${ }^{2}$ the dual-track system would soon lead to efficiency loss, rent seeking and institutionalised state 
opportunism (Balcerowicz 1994; Woo 1993; Sachs and Woo 1994, 1997; Qian and Xu 1993). Some economists even claimed that, despite its initial success, China's dual-track approach to economic transition would eventually lead the economy to a disastrous collapse (Murphy et al. 1992; Sachs et al. 2000).

At that time, most economists were optimistic about the transition in the former Soviet Union and Eastern Europe due to the fact that those countries were following policy recommendations based on the basic principles of existing modern economics - that is, neoclassical economics. ${ }^{3}$ The most representative of these policies was the 'shock therapy' implemented in Poland, the Czech Republic and Russia. Such an approach had three primary components: price liberalisation, rapid privatisation and macroeconomic stabilisation through elimination of fiscal deficits (Lipton and Sachs 1990; Blanchard et al. 1991; Boycko et al. 1995). These components are considered to be the basis of an efficient economic system in neoclassical economics.

Economists recommending shock therapy also knew the transition from one economic system to another took time and that it was costly to cast aside vested interests. Nevertheless, they predicted optimistically that the economies would grow after six months or a year, after an initial downturn resulting from implementation of the shock therapy (Brada and King 1991; Kornai 1990; Lipton and Sachs 1990; Wiles 1995). According to their arguments, the former Soviet Union and Eastern Europe would soon out-perform China, even though the first two had instituted their reforms much later than China. China's progress would be limited by inconsistencies in its economic system exacerbated by incomplete, dual-track reforms.

As described, however, China's average annual GDP and trade continued to grow at high rates-10.3 per cent and 15.2 per cent, respectively, in 19912000 - the former at higher rates than in the early reform period. Inflation, as measured by the retail price index, was 5.5 per cent per annum in the same period (NBS 2006). In the same 10 years, the countries that implemented shock therapy experienced serious inflation and economic decline. Russia's inflation rate reached 163 per cent per annum, while Ukraine's reached 244 per cent per annum in 1991-2000. The cumulative output decline in countries in central and southeastern Europe and the Baltic states reached 22.6 per cent; in countries of the Commonwealth of Independent States, output fell 50.5 per cent. In 2000, Russia's GDP was only 64 per cent of what it had been in 1990, while in Poland - the best performing economy in the former Soviet Union and Eastern Europe-GDP increased only 44 per cent, compared with 1990.

Meanwhile, the Gini coefficient of income per capita-a measurement of income disparity-increased from 0.23 in $1987-90$ to 0.33 in 1996-98 in countries 
of central and southeastern Europe and the Baltic states, and from 0.28 to 0.46 in countries of the Commonwealth of Independent States (World Bank 2002). Overall, the countries that implemented shock therapy experienced great difficulties in their reforms -in contrast with the optimistic expectations of most economists. Poland's economic record is the best among the countries of the former Soviet Union and Eastern Europe, however, it did not implement shock therapy completely. Although prices in Poland were liberalised, most of its large state-owned enterprises have yet to be privatised (World Bank 1996; Dabrowski 2001).

In the 1990s, the Chinese economy did suffer myriad problems, as predicted by those economists who favoured shock therapy. For example, the state-owned enterprise reforms initiated in the early 1980 s have yet to be completed. Interregional and urban-rural disparities increased after the decline in the 1980s. The financial system remains weak. As noted above, however, China's GDP and trade continued to grow. Moreover, living standards improved rapidly, especially in urban areas. Economic development in China not only promoted the welfare of the Chinese people, it contributed greatly to the world economy. During the East Asian financial crisis in 1997-98, the Chinese currency (the renminbi) did not depreciate, which played an important role in the quick recovery of the East Asian economies from the crisis.

China's economic transformation did not follow the standard policy prescriptions based on existing modern economics, and performed outstandingly. Those countries that followed the standard policy recommendations in their transitions performed poorly. This dramatic contrast indicates that there is an inherent limitation in established modern economics-represented by neoclassical economics-in analysing the problems in economic transitions. This chapter suggests directions for improvement of neoclassical economics.

\section{Neoclassical economics, the viability assumption and the formation of a planned economy}

Theories are used to explain and predict real-world phenomena. If they fail to do so, the theories must have some fundamental flaws and should be revised or abandoned (Friedman 1953). Existing neoclassical economic theories have performed reasonably well in explaining what happens in the economies of industrialised countries, but they have been less successful in explaining what happens in transitional economies and developing countries.

Neoclassical economics has a well-known assumption of rationality: given the choices available to a decision maker, he or she will choose what is considered to be the best option. There is, however, another assumption - the 'viability' 
assumption - that is incorporated implicitly by neoclassical economists in their analyses. The term 'viability' is defined with respect to the expected profit of a firm in an open, competitive market. If a normally managed company is expected to earn a socially acceptable normal profit in an open, competitive market, it is viable. For a non-viable company, its establishment or continuing operation is possible only if it receives external subsidies or protection. ${ }^{4}$

By implicitly assuming that all firms are viable in their analyses, economists will conclude that a firm that does not earn acceptable profits in an open, competitive market must lack normally efficient management. They infer that problems must stem from corporate governance, incentive mechanisms, property rights arrangements or other market intervention that impede the firm's management. Problems in corporate governance, property rights arrangements and so on did exist in socialist economies. Therefore, under the influence of existing neoclassical economic theories, it was believed that the success of state-owned enterprise reforms and the transition to a market economy depended on the elimination of those factors that impeded a company's normal management. Shock therapy is based on this theoretical foundation.

Since the inception of neoclassical economics, economists in industrialised countries have conducted most theoretical explorations. Their research, however, focuses mainly on issues relating to industrialised countries. It is reasonable for them to assume that firms are viable, since-except for those in a few sectors-governments in industrialised countries rarely provide subsidies and other types of support directly to companies. If a company with normal management is not expected to earn acceptable profits in the market, it will not be set up in the first place. If a non-viable firm is established due to misleading information or mistakes in judgment, investors will withdraw their investments and close down the firm. Consequently, firms that can survive in an open, competitive economy must be viable: that is, they are expected to earn acceptable profits under normal management. It is therefore appropriate to have an implicit viability assumption in neoclassical economics for analysing phenomena in industrialised countries.

As argued by Lin (2003), however, many firms in transitional economies and developing countries are not viable - that is, they cannot earn acceptable profits in an open, competitive market even though their management is normally efficient. The non-viability of these firms arises from the fact that the sector in which they operate, the products they produce and the technology they use in production are inconsistent with the economy's comparative advantage as determined by the factor endowment structure-namely, the relative abundance of labour, capital and natural resources. 
Figure 20.1 illustrates the idea of viability in an open, competitive market that produces only one product with two factors: capital and labour. Curve ' $I$ ' is an isoquant. Each point on the isoquant represents a specific technology or combination of capital and labour required to produce a given amount of product. ${ }^{5}$ The technology represented by ' $A$ ' is more labour intensive than that represented by ' $B$ '. In an open, competitive economy, the least-cost technology is the best. If ' $C$ ' is the isocost line in the economy, the adoption of technology ' $A$ ' costs the least, while the adoption of any other technology will make the firm incur losses in an open, competitive market. For example, if a firm adopts the technology represented by ' $\mathrm{B}$ ', it is expected to incur a loss equivalent to the distance from ' $C$ ' to $C_{1}$. Market competition will make firms that adopt technologies other than ' $A$ ' non-viable. Therefore, in an open, competitive market with given relative prices of labour and capital, the viability of a firm depends on its choice of technology. Only the firm that chooses the least-cost technology is viable.

Whether the economy's isocost line corresponds with ' $C$ ' or ' $D$ ' depends on the economy's endowment structure. When labour is relatively abundant and capital is relatively scarce, the isocost line will have the flatter slope of ' $C$ ' rather than ' $D$ '. When capital becomes relatively abundant and labour relatively scarce, the isocost line will change to something like Line D in Figure 20.1. Therefore, the viability of a firm in an open, competitive market depends on whether its choice of technology is consistent with the comparative advantage of the economy's endowment structure.

This conclusion can be extended to multi-product and multi-industry cases. That is, in an open, competitive market, whether a firm is viable depends on whether or not its industry, product and technology choices are consistent with the comparative advantages determined by the economy's endowment structure. ${ }^{6}$ If a firm's choices are not consistent with this condition, it cannot earn acceptable profit in an open, competitive market even under normal management and its survival requires government subsidies and/or protection.

A good example that illustrates the viability concept is the agricultural sector in Japan. The majority of farms in the Japanese agricultural sector are small and owned by individual owners/operators. There are, consequently, no problems of property rights and corporate governance. ${ }^{7}$ Japan is, however, a country endowed with only limited arable land and it has no comparative advantages in land-intensive agricultural products such as grain. It is also a high-wage country with no comparative advantages in labour-intensive agricultural products such as vegetables and fruit. Although Japan's agricultural sector is famous for its delicate, intensive cultivation, the survival of Japanese farms relies on high 


\section{Figure 20.1 Relative price of production factors and technique choice}

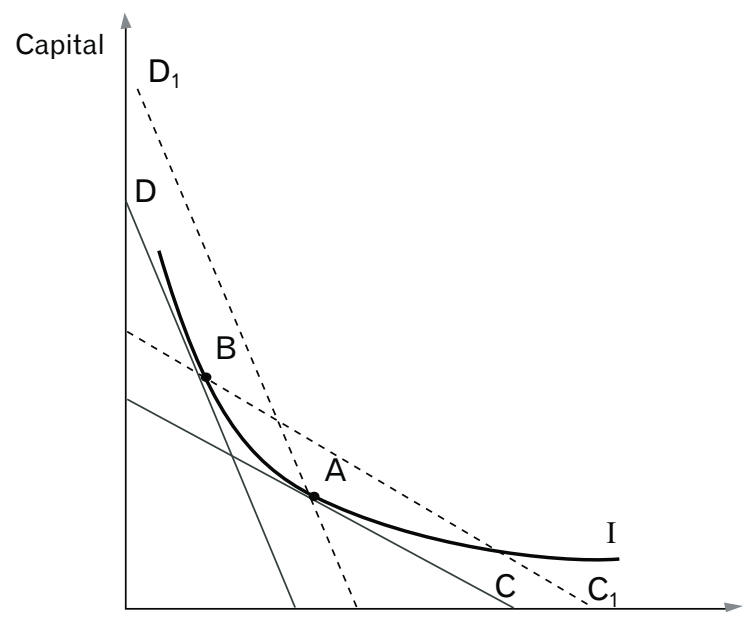

Labour

levels of government fiscal subsidies and tariff protections, without which most Japanese farms could not survive. ${ }^{8}$

Many state-owned enterprises in transitional economies face the same viability problems as Japanese farms, due to the fact that these enterprisesespecially large state-owned enterprises-are established by governments with the aim of competing with industrialised countries in capital and technologyintensive sectors, even though their economies are still low income and capital scarce. These strategies clash with the comparative advantages of the countries' particular economies.

In fact, the traditional centrally planned systems in socialist economies were formed endogenously to support and protect these non-viable heavy industrial firms that were not consistent with the economy's comparative advantages. ${ }^{9}$ Socialist countries-including Russia and China-were capital scarce, backward, agrarian economies before they adopted a centrally planned system. In a capital-scarce, agrarian, low-income country, the establishment of a firm in a capital-intensive heavy industry must overcome numerous difficulties. First, construction of the firm takes a long time. Second, the key equipment and technologies necessary for the firm must be imported. Third, the initial investment is dauntingly large. At the same time, in a low-income agrarian country, the economic surplus from each period of agricultural production is very small and scattered widely and thinly across numerous small rural farms. As a result, such an economy has three distinct characteristics. 
First, capital is relatively scarce due to the lack of economic surplus, making market-determined interest rates extremely high. Second, exportable goods are limited in variety and quantity. Consequently, foreign exchange is scarce and market-determined exchange rates are high. Third, the mobilisation of resources for a project that requires large, lump-sum investment is difficult due to the fact that the economic surplus is limited and scattered widely across the economy. The conflicts between the three characteristics of a low-income, agrarian country and the three characteristics of investing in capital-intensive heavy industries in the country require the government to adopt special institutional arrangements to make such investment feasible.

Specifically, to make long-gestation investment projects feasible in China, Russia and other socialist countries, governments artificially depressed interest rates; to lower the costs of imported equipment and technologies, governments distorted exchange rates by artificially overvaluing the domestic currency; and to mobilise enough surplus for the large, lump-sum investment projects, governments gave the firms monopolies in their output markets and artificially depressed prices of all kinds of inputs-including wages-so that the firm could accumulate enough surplus for its own investment. As wage rates were suppressed, governments were required to provide workers with low-price living necessities. The distortions in interest rates, foreign exchange rates, wage rates, inputs and the price of necessities resulted in shortages of capital, foreign exchange, raw materials and necessities. To ensure that these scarce resources would be allocated to firms in the priority sectors, planning and administrative allocation of resources according to the state plans were required. This was the logic for the emergence of a traditional, centrally planned system in socialist economies.

Furthermore, if the firms were in private hands, the state could not ensure that the surpluses mobilised through these distortions would be invested in heavy industries according to the state's plans. Therefore, the firms were nationalised so that the state could directly control the rights to invest the surplus. In addition, even though the firms were owned by the state, the state could not overcome the problems of information asymmetry and incentive incompatibility. If company managers had discretionary powers, moral hazards would ensue, resulting in a reduction of the surplus available for investment. To prevent the erosion of the surplus, the government deprived managers of any autonomy in input, output and market decisions and in personnel appointments, wage settings and other managerial discretions (Lin and Tan 1999).

In fact, the various institutional arrangements-such as distortions in interest rates, foreign exchange rates, prices of raw materials, wage rates and commodity prices, the replacement of the market mechanism with plan allocation, and the 
deprivation of managerial autonomy - are all endogenous to the fact that the firms in the government's priority sectors are not viable in an open, competitive market (Lin et al. 2003). In the jargon of neoclassical economics, these arrangements are 'second best'. They are required for the maximum mobilisation of surpluses in different sectors for investment in the priority sectors. With such arrangements, a backward agrarian country such as China could develop nuclear bombs and launch satellites within a short time. The resource allocation, however, was poor, due to investments being made in non-viable firms. The incentives for workers and managers were low due to the manager's lack of autonomy and the disconnection between performance and reward. As a result, the whole economy was inefficient. ${ }^{10}$ Moreover, without the government's intervention, an economy will import the goods produced in industries in which the economy does not have comparative advantages and export goods in industries in which the economy has comparative advantages.

Under the comparative advantage-defying (CAD) strategy, however, imports will become smaller due to efforts to produce goods that industries are supposed to import, and exports will become smaller due to the fact that resources are diverted from industries in which the economy has comparative advantages to industries in which it does not have comparative advantages. Therefore, the trade-dependent ratio-measured by the total value of exports and imports as a share of GDP—under the CAD strategy will be much smaller than in a country that follows the comparative advantage-following (CAF) strategy. The case of China is a good example. The trade-dependent ratio in 1978 was 9.75 per cent. After China made the transition from the old strategy, the ratio increased to 64.1 per cent in 2005 .

Most distortions in the socialist planned economies were formed endogenously by the government for the purpose of facilitating the development of non-viable firms in sectors that were not consistent with the economy's comparative advantages. Since many existing firms were not viable, it is not surprising that existing neoclassical economic theories-with their implicit viability assumption-cannot provide adequate solutions for problems in socialist and transitional economies. If the problem of non-viability is not eliminated, and if the government is unwilling or unable to let the nonviable firms go bankrupt, eliminating distortions and reforming institutional arrangements according to the existing neoclassical economic theories are likely to turn the arrangements from second best to third best. Therefore, the reforms, at best, will not achieve the intended effects and, at worst, will exacerbate the situation. 


\section{Neoclassical economics and policies of economic transition}

The model of the world we have in our minds will shape our understanding of the real world (North 2002). Existing neoclassical economic theories-formulated in industrialised market economies-have proved that ineffective corporate governance, deficient property rights arrangements and government intervention in resource allocation are harmful to economic efficiency. Economists trained in neoclassical economics tend to think that existing neoclassical economic theories are appropriate models for the analysis of problems in transitional economies when they observe familiar problems in corporate governance, property rights and government intervention. They fail to see the endogeneity of these problems to the non-viability of firms in the government's development strategy. Invited by governments in the former Soviet Union and Eastern Europe to design their transition policies, neoclassical economists reached a remarkable consensus about the need to eliminate the distortions and government intervention immediately (Summers 1994:252-3). ${ }^{11}$

The most prevalent reform policy advice according to neoclassical economic theories is the 'Washington consensus', which calls for strengthening fiscal discipline, increasing public investment in areas with 'public goods' characteristics to improve income distribution, enlarging the tax base, unifying exchange rates, liberalising trade, removing foreign direct investment (FDI) barriers, privatising state-owned enterprises, lifting regulations on market entry and protecting private property rights (Williamson 1997). The shock therapy proposed by economists for the transitional economies in the former Soviet Union and Eastern Europe was based on this Washington consensus (Kolodko 2001). Therefore, we can understand why, in the 1990s, economists with neoclassical training were more optimistic about reforms in the former Soviet Union and Eastern Europe, which implemented shock therapies, than about the piecemeal, gradual, dual-track reform approach being taken in China.

Neoclassical economic theories not only have an impact on economists working on issues related to industrialised market economies, they influence economists working on issues related to other economies. For example, in the famous debate on socialism in the 1930s, economists such as Oscar Lange, who believed that the socialist planned economy could achieve the same allocation efficiency by simulating markets, and Friedrich Hayek, who believed that the socialist economy was doomed to fail due to informational problems, took the viability of firms in a socialist economy as an implicit assumption in their analyses.

Neoclassical economic theories also influence economists living in socialist countries when they analyse the problems of their own economies. Janos Kornai 
of Hungary is one of the most eminent economists specialising in socialist economies. One of his most important contributions is the concept of the 'soft-budget constraint' (Kornai 1986). In many socialist countries, state-owned enterprises suffering from poor performance can ask for preferential treatment and subsidies, while private firms in market economies have no choice but to go bankrupt. Kornai proposed that the soft-budget constraint was the main reason for a lack of incentives to improve efficiency and for the prevalence of moral hazards in state-owned enterprises. He attributes the existence of the soft-budget constraint to the paternalism of socialist governments towards state-owned enterprises. Therefore, he argued that reform in property rights and the severance of firm-state connections must be carried out in order to eliminate the soft-budget constraint and to promote company efficiency.

In Kornai's theoretical framework, state-owned enterprises are implicitly assumed to be viable. However, the soft-budget constraint in socialist economies emerges essentially from the viability problem of state-owned enterprises. In an open, competitive market, these firms would not be able to attract investment in the first place and, if they had investment due to misjudgment or other reasons, investors would not continue to support their operations once the misjudgments were clarified. To establish these non-viable firms, socialist governments must protect and subsidise them. Because of incentive incompatibility, the managers of state-owned enterprises have incentives to attribute their losses to insufficient government support or protection, even though the losses arise from incompetent operations and poor managerial discretion. Because of information asymmetry, governments cannot know what levels of protection and subsidy are adequate. Therefore, governments cannot resist the companies' requests for more support and the companies' budget constraints become soft (Lin and Tan 1999). Therefore, the soft-budget constraint of state-owned enterprises results essentially from the problem of non-viability rather than from the paternalism of socialist governments. Similarly, even in non-socialist countries, the soft-budget constraint will exist in non-viable firms if the government is responsible for the establishment of those firms. The large chaebols in Korea are illustrative of this fact.

If the viability problem is the root of the soft-budget constraint, we can predict that if the viability problem is not solved, the soft-budget constraint will not be eliminated, even though the socialist government is overthrown and all firms are privatised. In fact, that is what happened in the former Soviet Union and Eastern Europe. In these countries, democratically elected governments replaced socialist governments and shock therapy and privatisation were implemented, but the soft-budget constraint still existed and in many cases 
incentives for privatised company managers to bargain for more support and protection became significantly higher than the incentives for state-owned enterprise managers..$^{12}$ According to the World Bank's studies, after full-scale privatisation in the former Soviet Union and Eastern Europe, the subsidies that firms received from governments did not decrease-in some cases, they even increased (World Bank 1996, 2002). ${ }^{13}$ At the same time, taxation capacities were weakened significantly after shock therapy. This, combined with high subsidies to companies, led to extremely high inflation in these countries.

It is not only that the shock therapy formulated according to neoclassical economic theories did not work in the former Soviet Union and Eastern Europe, many reform measures based on such theories or on the experiences of industrialised economies created problems in China. ${ }^{14}$ The reform of stateowned enterprises is an example..$^{15}$ At the beginning of the reforms in the early 1980s, it was believed that the root of the problems with state-owned enterprises was the lack of autonomy of managers, with disconnection between performance and rewards. Therefore, decentralisation reforms were initiated to increase managerial autonomy and to allow state-owned enterprises to retain a certain share of their profits to be used at their own discretion. These measures were effective in pilot experiments, but were ineffective when they were implemented nation-wide. Empirical studies found that the reform increased state-owned enterprises' productivity but their profitability declined (Lin et al. 2001).

Many scholars thought the discrepancy arose from the arrangement of property rights because the firms were owned by the state but were operated by managers, who were not the owners and did not have incentives to increase returns to the equity owner-the state. Based on this diagnosis, the reform measures, starting in the late 1980s, promoted modern corporate governance in state-owned enterprises with the establishment of boards of directors and supervision boards to delineate clearly the owners' rights. A publicly listed company was considered to have the best corporate governance and property rights arrangements, since the value of the firm would be evaluated before it went public and, after being listed, equity would be held by the state and nonstate investors. In addition to monitoring by the board of directors, non-state shareholders would have incentives to monitor the company's management and operations since they would care about the returns on their investment.

Nevertheless, in reality, after a few years, the financial performance of the majority of listed companies did not differ from those of non-listed companies (Lin 1999). In the beginning, the poor performance of listed companies was attributed to the fact that only small, individual investors owned the non-state 
stocks and these investors had little incentive to monitor the managers because the returns for their efforts would be negligible. These small shareholders were thought to be interested in the short-term price changes in stocks, which made stock-markets highly speculative, with high turnover rates and short holding periods.

In industrialised countries, institutional investors play an important role in equity markets. An institutional investor has the capacity to hold a substantial portion of a listed company's shares and thus has greater incentive to monitor the invested company's management than does an individual investor. In addition, an institutional investor can hire professionals to analyse the listed companies' reports and operations. If an institutional investor decides to hold the shares of a company, that investor is likely to hold the shares for a long time.

Chinese researchers thought that the introduction of institutional investors would stabilise China's stock-markets, so investment funds were introduced in 1998; however, speculation in the stock-markets did not stop. Making things worse, many investment funds not only speculated in the stock-market, they manipulated stock prices. How could this happen? The reason lies in the problem of the non-viability of these listed companies. Without the ability to earn acceptable profits in an open, competitive market, these companies cannot afford to distribute dividends to shareholders, which means that small individual shareholders as well as institutional investors can profit only through speculation on stock prices. With large amounts of money at their command and a small portion of stocks in circulation for each listed company, ${ }^{16}$ institutional investors resorted to manipulation of stock prices to make profits (Lin 2001, 2004).

In conclusion, for firms to survive in the markets of industrialised countries, they must be viable. Therefore, viability is an acceptable implicit assumption in neoclassical economic theories for explaining phenomena in industrialised countries. Policy reforms based on neoclassical economic theories or the experiences of industrialised countries have failed to achieve their intended goals in transitional economies because most firms in transitional economies are not viable.

\section{The prevalence of the viability problem and the expansion of the neoclassical framework}

Companies' viability problems and the resulting institutional arrangements not only appear in transitional economies, they are widespread in developing countries. On seeing the decisive role of industrialisation in promoting the economic and political powers of industrialised countries, many leaders of developing countries that achieved independence after World War II attempted 
to develop advanced industrial sectors comparable with those in industrialised countries against their own comparative advantages (Chenery 1961; Krueger 1992). ${ }^{17}$ They did so by intervening in factor prices, the financial system, international trade and investment-without realising that the industrial structures of industrialised countries were determined endogenously by their own particular factor-endowment structures. Through such efforts, developing countries were able to establish companies in advanced sectors. Those companies were not, however, viable in an open, competitive market, and government intervention on prices, resource allocation and market competition were required to ensure their survival. Such intervention led inevitably to the prevalence of rent seeking and crony capitalism, which resulted in unequal distribution of income, low efficiency and social and economic instability (Krueger 1974; Lin 2003). ${ }^{18}$

This phenomenon also existed in some newly industrialised economies. Korea's situation serves as a good illustration. Taiwan has higher per capita income than Korea, but the chaebo/s in Korea are more technologically advanced and capital intensive than comparable firms in Taiwan. ${ }^{19}$ During the East Asian financial crisis in 1998, Taiwan's foreign exchange rate devalued by only 15 per cent and it was the only economy that achieved positive growth in East Asiaexcept for Mainland China, which was insulated from the crisis by its currency inconvertibility and control of capital accounts. Taiwan grew by 4.5 per cent in 1997 and 5.7 per cent in 1998, which was remarkable considering the terrible external environment at that time. Taiwanese firms manifested themselves as being competitive and viable. The Korean economy collapsed during the East Asian financial crisis and Korea had to borrow heavily from the International Monetary Fund (IMF). After the elimination of state protection and subsidies to large firms -in accordance with the conditions of the IMF's rescue package-20 out of 30 Korean chaebols went bankrupt, which showed that these firms were not viable and could not survive without government protection.

In market economies, the protective measures provided to non-viable firms are similar to those in socialist economies: depression of interest rates, administrative allocation of bank loans to provide cheap funds to non-viable firms and establishment of various import barriers to prevent competition from industrialised countries. The protected firms are in sectors that clash with the economy's comparative advantages and produce little economic surplus. The firms, consistent with the economy's comparative advantages, face discrimination and eventually experience difficulties. As a result, the funds that could be mobilised for development purposes dry up. If external borrowing is not allowed - as was the case in India, Pakistan and most socialist 
countries-economies stagnate. If external borrowing by firms or governments is permitted-as in Latin America, Korea, Thailand and Indonesia before the East Asian financial crisis-debt crises ensue (Krueger 1992).

When debt crises occur, countries have to seek rescue packages from the IMF under existing international financial arrangements. Such packages usually come with conditions, requiring a series of reforms and structural adjustments in the recipient countries. The concept of such conditions is itself based on the Washington consensus, which requires that macro-policy distortions be corrected, that governments cease intervention in banks and companies and that corporate governance be improved. The Washington Consensus-reflecting the basic principles of neoclassical economic theories-implicitly assumes that firms are viable. Therefore, the conditions aim to eliminate protection and subsidies without any attempt to solve the companies' viability problems. If non-viable firms constitute only a small share of the economy-as is the case in Bolivia-shock therapy is possible and growth can resume quickly when increases in efficiency offset the shock of bankruptcy suffered by non-viable companies in the wake of Washington consensus measures. If, however, non-viable firms constitute a large share of the economy - as is the case in transitional economies-shock therapy would lead to an 'L' curve rather than a ' $J$ ' curve in the pattern of GDP growth after implementing the therapy (Lin 1998). ${ }^{20}$

Since the existence of non-viable firms is a common reality in socialist, transitional and developing economies, it is inappropriate to assume implicitly that companies are viable in the analysis of the economic problems in these economies and to formulate reform policies based on such assumptions and analyses. Problems of viability should be taken into consideration in analysing economic development and transition.

On reflection, neoclassical economics has been enriched through a process of abandoning unrealistic and implicit assumptions. The basic framework of neoclassical economics was laid down in Alfred Marshall's Principles of Economics in 1890. Among others, Marshall's framework had several implicit assumptions, including perfect information, zero transaction costs and the viability of firms in an open, competitive market.

Economic theories are instruments to help people explain what has been observed and to predict what will happen. According to Friedman (1953), the acceptability of a theory depends not on whether the assumptions of the theory are realistic, but on whether the implications drawn from the theory are consistent with empirical observations. Marshall's framework is very powerful in explaining and predicting a number of economic phenomena in market economies. For example, when the prices of certain products increase, 
purchases of those products will generally decline. The assumptions in Marshall's framework, however, also limit its explanatory power on certain issues. For example, under the assumption of perfect information and zero transaction costs, there will be only one price for a product in a competitive market, allowing little room for price differentiation.

One of the main contributions by George Stigler at the University of Chicago was to abandon the implicit assumption of perfect information and to introduce the concept of incomplete information into economics, with the added considerations of the value of information and the cost of information collection and processing. His contribution makes information an important variable in modern economic analysis. Other economists—such as Joseph Stiglitz, George Akerlof and Michael Spence-further emphasised that not only is information incomplete, it is often distributed asymmetrically among producers, consumers, principles and agents. Furthermore, according to Marshall's framework, resource allocation by markets is the most efficient option. Knowing this, it is difficult to explain why there are firms operating in accordance with non-market allocation mechanisms. Ronald Coarse contributed to neoclassical economics by abandoning the zero transaction cost assumption and initiating research on contracts, property rights and non-market institutions.

Economic theories are like maps. A map is not the real world; it is a convenient tool to help us understand the surrounding environment and what will be seen in different directions. Maps, by nature, must be simplified, but if some important landmarks are ignored or incorrect, the maps will mislead us. When we discover mistakes in a map, and similarly in a theory, corrections must be made. Due to the prevalence of viability problems in socialist economies, transitional economies and developing countries, the implicit assumption of viability should be relaxed in analysing the economic problems and designing policies to solve problems in these economies. Transition and reform policies should be designed according to the understanding that many firms are not viable. The success of transition and reform depends on the creation of conditions that make non-viable firms viable, in lieu of following shock therapy and Washington consensus reforms unconditionally.

In addition, the objective pursued in national development must be reformulated. Traditionally, political leaders, economists and the social élite in developing countries aimed to develop advanced technologies and industries similar to those of the most industrialised countries within the shortest time. The structures of industry and technology that are consistent with an economy's comparative advantages are, however, determined endogenously by the economy's existing factor endowment structure. Ignoring the existing 
differences between its own endowment structure and that of industrialised countries, the government in a developing country often tries hard with good intentions to develop the same industries and technologies as those in industrialised countries. In effect, the government's efforts make companies in the priority sectors non-viable because they lack the ability to survive in open, competitive markets. Therefore, the government has to subsidise and protect these companies through price distortions, intervention in resource allocation, and so on. Rent seeking, the soft budget constraint, macroeconomic instability, income disparities, stagnation and crises are the consequences of the government's development attempts in spite of the initial good intentions.

Based on the concept of viability, the objective of national economic development should be to upgrade the economy's endowment structure. With such upgrading, companies in open, competitive markets will upgrade their industrial, product and technological levels accordingly in order to ensure their competitiveness in the market (Lin 2003). Since the endowment of land (and natural resources) in a country can be treated as given, the upgrading of the endowment structure means an increase in the amount of capital to each worker. Capital comes from the accumulation of economic surplus. To upgrade the endowment structure rapidly, a maximum economic surplus should be produced in each period, and a large proportion of this surplus should be saved for capital accumulation. If a country develops its industries, technologies and products along the lines of its existing comparative advantages, its economy will be most productive, produce the maximum possible surpluses, create the highest possible returns to capital and have the highest incentive to save. Consequently, the upgrading of the factor endowment structure in the economy will proceed at its maximum speed. Companies' decisions will be based on product prices and production costs, but not on the factor endowment structure in the economy. Therefore, the government should maintain openness and sufficient competition in the market so that the price structure will reflect the relative abundance of the factor endowment structure. ${ }^{21}$

\section{Viability and economic transition}

Companies in heavy industries prioritised by the government in traditional centrally planned economies are not viable in open, competitive markets. The objective of the transition from a traditional centrally planned economy is to establish an open, competitive market economy. In the process of transition, however, the viability problem of those firms in the sectors inconsistent with the economy's comparative advantages turns from implicit to explicit. Whether the transition will be stable and successful depends very much on how the viability problem is solved. 
Non-viable firms cannot survive in open, competitive markets without government subsidies or protection. The shock therapy adopted in the former Soviet Union and Eastern Europe attempted to eliminate all distortions and government intervention simultaneously, or in a short period. If implemented forcefully, shock therapy inevitably led to large-scale bankruptcy and unemployment, thus prompting economic collapse and social instability. Such results are, understandably, not acceptable to a functioning government. Consequently, many governments in the former Soviet Union and Eastern Europe had to find ways to provide protection or subsidies continuously to a large number of non-viable firms, resulting in the embarrassing situation of shock without therapy (Galbraith 2002).

China has adopted a gradual, piecemeal, dual-track approach since its transition started in 1979: on one hand, the Chinese government has relaxed its strict control of resource allocation and has allowed new entries to sectors in which the economy has comparative advantages; on the other hand, the government has continued to provide protection and support to firms in traditional sectors to buffer them against the threat of bankruptcy, while taking measures to reform them. The first track enhanced the efficiency of resource allocation, created a new stream of resources and resulted in rapid economic growth and trade expansion. The second track prevented the collapse of the economy during the transition process. This dual-track approach has maintained social and economic stability, achieved dynamic growth and ensured the transition has been a Pareto or Kaldor improvement (Lin et al. 1996).

China's transition towards a market economy depends, however, on a final solution to the viability problem of firms in traditional sectors. Since the viability problem is not yet solved, the Chinese government has been required to continue its intervention in markets in order to protect or subsidise nonviable firms - and such intervention comes with consequences. For example, along with China's rapid economic growth in the transition process, the share of non-performing loans in the four big state-owned commercial banks has increased sharply, corruption is widespread and regional income disparities are widening. To a large extent, these problems arise from the fact that state-owned enterprises still depend on government subsidies and protection to survive. After 1983, the form of Chinese government support to state-owned enterprises changed from direct fiscal appropriation to offering low-interest loans from the four state banks. Until now, more than 70 per cent of loans from the four state banks went to state-owned enterprises, but due to their poor performance, many state-owned enterprises have been unable to repay the loans. Therefore, the banks have accumulated large amounts of non-performing loans. 
The government also limits the market entry of private interests into certain sectors to give state-owned enterprises in those sectors a monopoly position. Therefore, rent seeking to obtain preferential loans or market-entry licences is prevalent among state-owned and non-state-owned enterprises, adding to widespread corruption. In addition to subsidising state-owned enterprises, the government artificially depressed the prices of agricultural products and minerals under the traditional planning system. Such price distortion has continued since the reforms as a means to subsidise the non-viable stateowned enterprises.

The comparative advantages of eastern China lie in manufacturing industries; those of central China lie in agriculture; and those of western China lie in minerals and natural resources. Since the reforms began, the eastern region has made huge progress in the development of manufacturing industries by taking advantage of the superior geographical and market conditions and has increased substantially imports of low-priced agricultural and mineral products from the central and western regions. In essence, the relatively poor central and western regions have been subsidising the development of the relatively rich eastern, industrial region. Regional disparities are widening as a result. If the viability problem of state-owned enterprises is solved, there will be no reason to continue subsidisation and protection through low-interest loans, monopolistic practices and the depression of prices for agricultural and raw materials. The remaining distortions and government intervention can then be eliminated (Lin et al. 2001). ${ }^{22}$

The viability problem of state-owned enterprises can be solved according to four different strategies, depending on the nature of the state-owned enterprises' outputs (Lin et al. 2001). The first group includes mainly the defence-related state-owned enterprises, whose production-which is capital and technology intensive-runs against China's comparative advantages, but whose outputs are essential for national security. For this group of state-owned enterprises, direct fiscal appropriation is necessary for their survival and the government should directly monitor their production and operation. It is reasonable to expect that there are only a few state-owned enterprises in this category.

The second group also requires intensive capital and technological inputs for their production, but their outputs are not sensitive to national security and they have large domestic markets. Examples of this category are the telecommunications and automobile industries. For this category, the government can adopt a 'market-for-capital' approach to gain access to capital from international markets and remove the adverse impact of the domestic endowment structure on these firms' viability. There are two ways to achieve this 
goal: one is to encourage state-owned enterprises to go public on international equity markets; the second is to set up joint ventures with foreign companies and gain direct access to foreign technologies and capital. China Mobile, China Telecom and China Petroleum have followed the first approach and many automobile makers in China have followed the joint-venture approach.

The third category of state-owned enterprises has limited domestic markets for their products and thus this group cannot adopt the market-for-capital approach. The way for them to solve the viability issue is to make use of their engineering and managerial capacities and to shift their production to labourintensive products, which have large domestic markets and are also consistent with China's comparative advantages. The most famous example of a firm following this approach is the colour-television maker Changhong. This firm used to produce old-style military radar. After switching to the production of colour televisions, the firm has dominated the Chinese market and is very competitive in the international market. Most state-owned enterprises have advantages in engineering and managerial personnel. If they are given the opportunity to shift their production lines to labour-intensive products, many of them can become viable. The fourth group consists of non-viable firms that lack engineering capacity and are thus unable to shift their production to new markets. These state-owned enterprises should be allowed to go bankrupt.

After the viability problem of the existing firms is solved, whether or not a firm can earn acceptable profits in an open, competitive market becomes the responsibility of the firm's managers. The performance of a firm will depend on the corporate governance, incentive mechanisms and other factors-as identified in neoclassical economics. The government will no longer be responsible for a firm's performance. Only then can the reform of institutions that are inherited from the traditional centrally planned system, with the functions of subsidising and protecting state-owned enterprises, be carried out thoroughly and the transition from a planned economy to a market economy be completed.

\section{Conclusion}

In this chapter, I have shown that modern neoclassical economics did not play a direct role in helping China's formulation of successful transition policies to a market economy and that those countries that followed transition policies based on modern neoclassical economics performed poorly in the process. The reason for the failure of neoclassical economics to provide useful policy guidance for transition is because its current framework, beginning with Marshall, implicitly assumes that a company existing in the market is viable: that is, the company 
is expected to earn a socially acceptable profit in an open, competitive market as long as it is under normal management. With this implicit assumption, the focus of economic research has been on the problems of corporate governance, the competitive environment, the arrangement of property rights and other factors that can obstruct a firm's normal management.

Many firms in transitional economies and developing countries are, however, not viable because, due to their governments' ambitious development strategies, they are in sectors that are inconsistent with their economies' comparative advantages. In an open, competitive market, these firms, even under normally efficient management, will not be able to earn acceptable profits. To set up these firms and to maintain their continuous operation, governments provide them with protection and subsidies through price distortion, limitations on market competition, administrative allocation of all kinds of resources, and so on. The results of such intervention are inadequate competition, lack of effective corporate governance, rent seeking, disparities in income distribution, inefficient resource allocation and, quite possibly, economic crisis.

Under the rubric of existing neoclassical economic theories, when designing policies for economic transition or crisis management, economists and government officials are likely to focus on strengthening property rights, improving corporate governance, removing government intervention in resource allocation, and so on, to improve the efficiency of the market. They are not aware of the fact that such market-impeding distortions and interventions are, in fact, endogenous to a company's viability problem. When a majority of the companies in an economy are non-viable, the implementation of these reform and transitional policies sometimes leads to an awkward situation of shock without therapy, as in the former Soviet Union and Eastern Europe, and the lost decades in other developing countries (Easterly 2001; Lin and Liu 2004).

Since many existing companies in socialist centrally planned economies, transitional economies and developing countries are not viable, it is necessary to relax the implicit viability assumption in neoclassical economics when applying the neoclassical approach to study the problems in those economies. The explicit consideration of the viability problem will enrich neoclassical economics and help to define the economic functions of governments in developing countries, preventing them from adopting CAD development strategies to set up non-viable firms and enabling them to achieve convergence with industrialised nations in an expedient manner (Lin 2003). 


\section{Notes}

1 There were also economists who held China's reform in high regard. They include Jefferson and Rawski 1995; McKinnon 1994; McMillan and Naughton 1992; Naughton 1995; Singh 1991; Harrold 1992; Perkins 1992; and Murrell 1991, 1992.

2 The initial conditions that have been regarded as beneficial to China's transition include high proportions of cheap rural labour, low social security subsidies, a large population of overseas Chinese and a relatively decentralised economy, which helped to achieve some short-term progress.

3 The critique in this chapter is on the existing economic theories, which assume implicitly that the existing firms in a market are viable, rather than on the neoclassical economic approach, which assumes that a decision maker is rational: that is, he or she will make a choice considered to be the best among his or her available choices. I owe this clarification to Gary Becker.

4 The term viability was introduced formally in Lin and Tan 1999. The most comprehensive analysis of this concept can be found in Lin 2003.

5 The curve can be considered as the envelope of all different kinds of technologies that can be used to produce the product.

6 For detailed discussions of a firm's viability issues in a multi-good and multi-sector context, see Lin 2003. The term viability refers only to whether a firm's choices of technology and product are consistent with comparative advantage determined by the economy's endowment structure. It is noteworthy that a viable firm might not be profitable if its management is poor.

7 The problem of corporate governance is due to the separation of ownership and control that leads to incentive incompatibility and information asymmetry between owners and managers. If the same person is owner and manager of a firm, there will be no problems of incentive incompatibility, information asymmetry and moral hazard.

8 The price of rice in Japan is about eight times that in the international market. Japan's deflation has lasted for more than a decade, since 1991. The formation of the Free Trade Area of the Association of South East Asian Nations (ASEAN) Plus Three-including Japan, Korea and China-stands to increase Japan's exports and FDI and will help Japan get out of its current deflation. China proposed the ASEAN Plus Three Free Trade Area in 2001, but Japan's response was hesitant due to its need to protect its agricultural sector.

9 On the logic of the formation of a traditional planning system in socialist countries, see Lin et al. 2003.

10 For efficiency indicators for China before the transition, see Lin et al. 2003:Chapter 3. For a detailed study of efficiency in the former Soviet Union, see Desai 1990.

11 Certainly, there were exceptions. For example, Murrell 1991 questioned the power of the neoclassical paradigm to explain the differences in the economic performance of market and centrally planned economies and the appropriateness of using neoclassical economics to underpin the reform of centrally planned economies.

12 Before the introduction of shock therapy, firms were state owned and managers were civil servants of the state. The subsidies they received from the government could not fall into their own pockets without the managers facing the possibility of corruption charges. After privatisation, however, government subsidies could be channelled into the legal incomes of managers. Thus, the incentive to push for subsidies and preferential treatment increased and the problem of the soft-budget constraint became all the more serious.

13 According to empirical research, some firms increased their efficiency after privatisation, but others did not (Lavigne 1995:175; Djankov and Murrell 2002). In my judgment, the key lies in whether or not the firm was viable before privatisation. If it was, then efficiency would increase after privatisation; if it was not, such firms would experience a decrease in efficiency. After 
seeing that privatisation did not help solve the soft-budget constraint or improve efficiency, many economists realised the importance of improving corporate finance and market competition. As former Chief Economist of the European Bank and Vice-President and Chief Economist of the World Bank, Nicolas Stern, commented, '[G]ood corporate governance of public firms and sound competition policy are at least as essential for recovery as privatization and liberalization' (Stern 1996:8). Poland's former First Deputy Premier and Minister of Finance, Grzegorz Kolodko (2000:Ch.4), holds the same opinion. The fact that many shareholding companies in China did not show significant differences in their financial indicators from non-listed companies after five years of being listed shows, however, that if the problem of viability goes unresolved, good corporate governance and sufficient market competition will not come about unless bankruptcy is permitted (Lin and Tan 1999; Lin et al. 2003).

14 Since 1978, when China initiated its reforms, the two most significant changes-summarised by Deng Xiaoping as the two 'unexpected results'-were the success of the household responsibility system (Lin 1992) and the remarkable growth of township and village firms (Lin and Yang 2001). These reforms were not designed by reformers ex ante, but adopted by peasants spontaneously in practice.

15 Regarding academic debates and policy measures on state-owned enterprise reform, see Lin et al. 2001.

16 In China, about only 25 per cent of the total stock of a listed company was issued to non-state investors and could be traded in the stock-markets. The other 75 per cent was still owned by the state and could not be traded in the stock-market. Among the 1,200 or so listed companies, only a few have distributed dividends to stockholders (Lin 1999).

17 The view of former Indian Prime Minister Jawaharlal Nehru is most representative of this. In 1938, before India's independence, he was the President of India's State Planning Commission. He wrote: '[l]n the context of the modern world, no country can be politically and economically independent, even within the framework of international interdependence, unless it is highly industrialized and has developed its power resources to the utmost. Nor can it achieve or maintain high standards of living and liquidate poverty without the aid of modern technology in almost every sphere of life' (Nehru 1946:413, quoted in Srinivasan 1994:155-6).

18 Such tendencies characterise India and Latin America. On India, see Swamy 1994. On Latin America, see Cardoso and Helwege 1992.

19 Take the information technology (IT) sector as an example. Taiwanese firms, such as TSMC, mainly do original equipment manufacture (OEM), while Korea's Samsung and Hyundai Electronics carry out independent research and development and product innovation. For a comparative study of IT development strategies in Taiwan and Korea, see Lin 2000. Furthermore, in the automobile industry, Korea produces complete cars, while Taiwan is renowned only for parts production.

20 The difference in the shares of non-viable firms in the economy might explain why the shock therapy recommended by Sachs succeeded in Bolivia but not in the former Soviet Union and Eastern European economies. Bolivia is a poor, small economy and the resources that the government could mobilise to subsidise the non-viable firms were small. Therefore, the share of non-viable firms in the economy must also be relatively small. Stiglitz 1998 also questioned the universal applicability of the Washington consensus, but did not consider the possible impact of non-viable firms in developing and transitional economies and their limitations on policy choices.

21 In a developing country, the government can also use an industrial policy to assist firms' upgrading of technology, product and industry in responding to change in the economy's endowment structure by providing relevant information, coordinating required investments and compensating for externalities of innovation. The industry promoted by the industrial 
policy should, however, be consistent with the comparative advantages of the new endowment structure and, as such, the firms are viable in an open, competitive market (Lin 2003).

22 Besides the viability problem, state-owned enterprises in China have a problem of social burdens. Before the economic transition, the investment in heavy industry provided limited employment opportunities. The government was responsible for urban employment and usually assigned several workers to a job, resulting in labour redundancy in state-owned enterprises. The workers also received low wages, which were enough only for covering current consumption. Before the transition, state-owned enterprises remitted all their revenue to the government, and the government used fiscal appropriation to cover state-owned enterprises' wages, the pensions of retired workers and other expenditure. Therefore, the labour redundancy and pension expenditure were not burdens on the state-owned enterprises. After the reforms, state-owned enterprises started to be responsible for their workers' wages and retirement pensions. The newly established town and village enterprises, joint ventures and other non-state firms are in sectors that are consistent with China's comparative advantage and they do not have the problem of labour redundancy and unfunded pensions for retired workers. I call the issue arising from the viability problem of the state-owned enterprises the 'strategic burden' and the additional cost arising from labour redundancy and pension expenditure the state-owned enterprises' 'social burden'. Together, they constitute the stateowned enterprises' 'policy burdens'. As long as these policy burdens exist, the government is responsible for the firms' losses and the soft-budget constraint cannot be eliminated (Lin and Tan 1999). There is a consensus in China about the necessity for and the way to eliminate social burdens. Therefore, the remaining issue is how to solve the strategic burden.

\section{References}

Balcerowicz, L., 1994. 'Common fallacies in the debate on the transition to a market economy', Economic Policy, 9:16-50.

Blanchard, O., Dornbusch, R., Krugman, P., Layard, R. and Summers, L., 1991. Reform in Eastern Europe, MIT Press, Cambridge, MA.

Boycko, M., Shleifer, A. and Vishny, R., 1995. Privatizing Russia, MIT Press, Cambridge, MA.

Brada, J.C. and King, A.E., 1991. Sequencing measures for the transformation of socialist economies to capitalism: is there a J-curve for economic reform?, Research Paper Series, No.13, Socialist Economies Reform Unit, World Bank, Washington, DC.

Cardoso, E. and Helwege, A., 1992. Latin America's Economy: diversity, trends and conflicts, MIT Press, Cambridge, MA.

Chen, K., Wang, H., Zheng, Y., Jefferson, G. and Rawski, T., 1998. 'Productivity change in Chinese industry: 1953-1985', Journal of Comparative Economics, 12:570-91.

Chenery, H.B., 1961. 'Comparative advantage and development policy', American Economic Review, 51:18-51.

Dabrowski, M., 2001. 'Ten years of Polish economic transition, 1989-1999', in M.I. Blejer and M. Skreb (eds), Transition: the first decade, MIT Press, Cambridge, MA:121-52. 
Desai, P., 1990. The Soviet Economy: problems and prospects, Reprint edition, Blackwell, New York.

Djankov, S. and Murrell, P., 2002. Firm restructuring in transition: a quantitative survey, Discussion Paper Series, No.3319, National Bureau of Economic Research, Cambridge, MA.

Easterly, W., 2001. 'The lost decades: developing countries' stagnation in spite of policy reform 1980-1998', Journal of Economic Growth, 6:135-57.

Friedman, M., 1953. 'The methodology of positive economics', in Essays in Positive Economics, University of Chicago Press, Chicago.

Galbraith, J.K., 2002. 'Shock without therapy', The American Prospect (online), 13.

Gregory, P. and Stuart, R., 2001. Russian and Soviet Economic Performance and Structure, Seventh edition, Addison Wesley, New York.

Harrold, P., 1992. China's reform experience to date, World Bank Discussion Paper 180, World Bank, Washington, DC.

Hayek, F.A. (ed.), 1935. Collectivist Economic Planning, Routledge and Kegan Paul, London.

Jefferson, G. and Rawski, T., 1995. 'How industrial reform worked in China: the role of innovation, competition, and property rights', Proceedings of the World Bank Annual Conference on Development Economics 1994, World Bank, Washington, DC:129-56.

Kolodko, G.W., 2000. From Shock to Therapy: the political economy of postsocialist transformation, Unu/Wider Studies in Development Economics, Helsinki.

- - 2001. 'Postcommunist transition and post-Washington consensus: the lessons for policy reforms', in M.I. Blejer and M. Skreb (eds), Transition: the first decade, MIT Press, Cambridge, MA:45-83.

Kornai, J., 1986. 'The soft budget constraint', Kyklos, 39:3-30.

- - 1990. The Road to a Free Economy, Norton, New York.

Krueger, A.O., 1974. 'The political economy of the rent-seeking society', American Economic Review, 64:291-303.

_- 1992. Economic Policy Reform in Developing Countries, Basil Blackwell, Oxford.

Lange, O., 1937. 'On the economic theory of socialism', Review of Economic Studies, 4:53-71, 123-42.

Lavigne, M., 1995. The Economics of Transition: from socialist economy to market economy, St Martin's Press, New York.

Lin, J.Y., 1992. 'Rural reforms and agricultural growth in China', American Economic Review, 82:34-51. 
1998. 'Transition to a market-oriented economy: China versus Eastern Europe and Russia', in Y. Hayami and M. Aoki (eds), The Institutional Foundations of East Asian Economic Development, St Martin's Press in association with the International Economic Association, New York:215-47.

- - 2000. 'IT development and the principle of comparative advantage', World Economy and China, 8(4):3-9.

_-, 2001. 'Four problems of China's stock market', CCER Briefing (in Chinese), 7.

- —, 2003. 'Development strategy, viability and economic convergence', Economic Development and Cultural Change, 53:277-308.

- - 2004. 'Viability and the development of China's capital markets', China and World Economy, 12(6):3-10.

- - 2005. 'Viability, economic transition, and reflection on neoclassical economics', Kyklos, 58(2):239-64.

Lin, J.Y. and Liu, M., 2004. 'Development strategy, transition and challenges of development in lagging regions', in F. Bourguignon and B. Pleskovic (eds), Annual World Bank Conference on Development Economics 2004: accelerating development (Bangalore conference proceedings), World Bank, Washington, DC.

Lin, J.Y. and Tan, G., 1999. 'Policy burdens, accountability, and the soft budget constraint', American Economic Review: papers and proceedings, 89:426-31.

Lin, J.Y. and Yao, Y., 2001. 'Chinese rural industrialization in the context of the East Asian miracle', in J.E. Stigilitz and S. Yusuf (eds), Rethinking the East Asian Miracle, Oxford University Press, Oxford and New York:143-95.

Lin, J.Y., Cai, F. and Li, Z., 1996. 'The lessons of China's transition to a market economy', Cato Journal, 16:201-31.

- - 1999. 'Competition, policy burdens, and the state-owned enterprise reform', American Economic Review: papers and proceedings, 88:422-7.

_- 2001. China's State-Owned Firm Reform, Chinese University of Hong Kong Press, Hong Kong.

-_, 2003. China's Miracle: development strategy and economic reform, Revised edition, Chinese University Press, Hong Kong.

Lin, J.Y., 1999. 'The third institutional innovation in the security market and the state-owned firm reform', Jingji Yanjiu (Economic Research), 10:46-52.

Lin, J.Y. et al., 1994. 'The impacts of hybrid rice on input demand and productivity: an econometric analysis", Agricultural Economics, 10:153-64.

Lipton, D. and Sachs, J., 1990. 'Privatization in Eastern Europe: the case of Poland', Brookings Papers on Economic Activities, 2:293-341.

McKinnon, R.I., 1994. 'Gradual versus rapid liberalization in socialist 
economies: financial policies and macroeconomic stability in China and Russia compared', Proceedings of the World Bank Annual Conference on Development Economics 1993, World Bank, Washington, DC:63-94.

McMillan, J. and Naughton, B., 1992. 'How to reform a planned economy: lessons from China', Oxford Review of Economic Policy, 8:130-43.

Murphy, K.M., Shleifer, A. and Vishny, R.W., 1989a. 'Income distribution, market size, and industrialization', Quarterly Journal of Economics, 104:537-64.

——, 1989b. 'Industrialization and big push', Journal of Political Economy, 97:1,003-26.

——, 1992. 'The transition to a market economy: pitfalls of partial reform', Quarterly Journal of Economics, 107:889-906.

Murrell, P., 1991. 'Can neoclassical economics underpin the reform of centrally planned economies?', Journal of Economic Perspectives, 5:59-76.

——, 1992. 'Evolutionary and radical approaches to economic reform', Economic Planning, 25:79-95.

_- 1995. 'The transition according to Cambridge, MA', Journal of Economic Literature, 33:164-78.

National Bureau of Statistics (NBS), 2002. China Statistical Abstracts, 2002, China Statistical Press, Beijing.

_-, 2006. China Statistical Abstracts, 2006, China Statistical Press, Beijing.

Naughton, B., 1995. Growing Out of the Plan: Chinese economic reform 1978-1993, Cambridge University Press, New York.

Nehru, J., 1946. The Discovery of India, John Day Company, New York.

North, D.C., 2002. 'The process of economic change', China Economic Quarterly, 1:797-802.

Perkins, D.H., 1988. 'Reforming China's economic system', Journal of Economic Literature, 26:601-45.

- - 1992. China's gradual approach to market reforms, UNCTAD Discussion Paper No. 52, Geneva.

Qian, Y. and Xu, C., 1993. 'Why China's economic reforms differ: the M-form hierarchy and entry/expansion of the non-state sector', The Economics of Transition, 1:135-70.

Rawski, T., 1995. 'Implications of China's reform experience', China Quarterly, 144:1,150-73.

Sachs, J.D. and Lipton, D., 1990. 'Poland's economic reform', Foreign Affairs, 69:47-66.

Sachs, J.D. and Woo, W.T., 1994. 'Structural factors in the economic reforms of China, Eastern Europe and the Former Soviet Union', Economic Policy, 18:101-45. 
- - 1997. Understanding China's economic performance, NBER Working Papers 5935, National Bureau of Economic Research, Cambridge, MA.

Sachs, J.D., Woo, W.T. and Yang, X., 2000. 'Economic reforms and constitutional transition', Annals of Economics and Finance, 1:435-91.

Singh, I.J., 1991. China and Central and Eastern Europe: is there a professional schizophrenia on socialist reform, Research Paper Series, 17, Socialist Economies Reform Unit, World Bank, Washington, DC.

Srinivasan, T.N., 1994. Agriculture and Trade in China and India: policies and performance since 1950, ICS Press, San Francisco.

Stern, N., 1996. 'The transition in Eastern Europe and the former Soviet Union: some strategic lessons from the experience of 25 countries over 6 years', OECD/CCET Colloqium, Paris, 29-30 May.

Stiglitz, J., 1998. More instruments and broader goals: moving toward the postWashington consensus, WIDER Annual Lecture 2, United States University World Institute for Development Economics Research, Helsinki.

_- , 1999. 'Whither reform? Ten years of the transition', Annual World Bank Conference on Development Economics, World Bank, Washington, DC, 28-30 April.

Summers, L., 1994. 'Comment', in O.J. Blanchard, K.A. Froot and J. Sachs (eds), The Transition in Eastern Europe, Vol. 1, Chicago University Press, Chicago:252-53.

Swamy, D.S., 1994. The Political Economy of Industrialization: from self-reliance to globalization, Sage Publications, New Delhi.

Wiles, P., 1995. 'Capitalist triumphalism in the Eastern European transition', in H.-J. Chang and P. Nolan (eds), The Transformation of the Communist Economies, Macmillan Press, London:46-77.

Williamson, J., 1997. 'The Washington consensus revisited', in L. Emmerij (ed.), Economic and Social Development into the XXI Century, Inter-American Development Bank, Washington, DC.

Woo, W.T., 1993. 'The art of reforming centrally planned economies: comparing China, Poland and Russia', Paper presented at the Conference of the Tradition of Centrally Planned Economies in Pacific Asia, Asia Foundation in San Francisco, San Francisco.

World Bank, 1996. World Development Report: from plan to market, Oxford University Press, Oxford.

_- 2002. Transition: the first ten years, analysis and lessons for Eastern Europe and the Former Soviet Union, World Bank, Washington, DC.

\section{Acknowledgment}

This chapter draws heavily on Lin (2005). 